\title{
Cruise industry in Romania - An emerging market
}

\author{
Emanuela ANTON \\ Bucharest University of Economic Studies, Bucharest, Romania \\ antonc.emanuela@gmail.com
}

PICBE $\mid 528$

\begin{abstract}
Cruise tourism has experienced an enormous growth in the last few decades and the future of this industry is also encouraging. The Caribbean and the Mediterranean Sea, the two major destinations, offer the most exciting itineraries since the beginning of this industry. The cruise passenger's perception about destinations, onboard and onshore aspects have been less investigated in the past years but this information shall be used for planning and developing marketing materials, new cruise itineraries, ship designs and shore excursions. The following study was conducted in Romania and aims to clarify the Romanian passenger's perception about cruise destinations and their preferences. Using a quantitative method, the research is based on some of the most representative international studies as well as a survey sent to the most active customers of a cruise travel agency in Romania, who have shown interest in this kind of trip at least once. As a qualitative research method, a convenience sample of participants were recruited through the researcher's professional contacts in the cruise and travel industry. Among other conclusions following this research, the most important aspect for a Romanian guest is the itinerary of the cruise ship, followed by the price and the embarkation port. The number of sea days, the service quality onboard and the cruise line are also relevant when choosing a cruise vacation.
\end{abstract}

Keywords: cruise tourism, Romanian market, demand, perception, cruise destinations.

\section{Introduction}

The emergence of the modern cruise industry started in the late '60 with the foundation of a cruise company named Norwegian Cruise Line in 1966, followed by Royal Caribbean International in 1968 and Carnival Cruise Lines in 1972 which have remained the largest cruise lines in the world, ever since (Garin, 2005). The main goal of the cruise industry was to develop a mass market since cruising was considered in the past accessible only for the elite. The first dedicated cruise ship was launched in 1970s and could offer accommodation to 1000 passengers. By the 1980s, the cruise lines built ships that could carry about 2000 passengers. The largest cruise ships nowadays have a capacity of about 6000 passengers and can compete with a well-known resort from Las Vegas or Orlando.

Cruise tourism has experienced tremendous growth in last few decades and the future of this industry is also encouraging. According to Cruise Line International Association (CLIA), in 2019 the number of passengers is expected to grow to 30 million which means an increase of 1.8 million, compared to the previous year. The Caribbean and the Mediterranean Sea, the two major destinations, offer the most interesting itineraries (Mancini, 2004) which represent approximately 54.5 and 26 percent, of the world traffic, respectively (Cruise Market Watch, 2018). This growth has helped increase revenue for both cruise lines and destinations (Whyte, 2018) and the new 18 ships that will be launched in 2019 show signs of continued development in this industry. 
In the next years, the continued increase in ship size will allow them to become the central point for passengers when choosing a cruise product and the ships will be more than just a means of travel. The average number of tourists in a port of call would pressure the Port Authorities to expand the infrastructure in order to receive the new larger cruise ships (Karlis, Polemis, 2018)

According to Collins English Dictionary a cruise is defined as "to make a trip by sea in a liner for pleasure, usually calling at a number of ports" (Dowling, 2006).

The cruise passenger's perception about destinations, onboard and onshore aspects has been less investigated in the past years but there is an increasing competitiveness in this industry due to emerging markets in Europe, Asia, Australia and the Pacific (Business Research \& Economic Advisors, 2018) showing that also cruise lines and ports of call should understand better on how passengers perceive the cruise destination. Understanding those perceptions with both onboard and onshore aspects, could provide useful information for the cruise lines and destination ports in order to develop and promote the cruise experience (Whyte, 2018). This information shall be used for planning and developing marketing materials, new cruise itineraries, ship designs and shore excursions.

A new trend in the cruise industry is to build ships designed for a specific geographic region as the giant Majestic Princess vessel was designed to serve the Chinese market. This coin has two sides because it could restrict the flexibility of cruise line to reposition the ship to different regions seasonally which is a unique strength of the industry that helped maintain profitability and growth for the business (Whyte, 2018).

Over the years, the cruise tourism industry had an enormous growth in terms of passengers' number, variety of destinations, amazing new ships, all designed to meet a higher demand for cruise vacations that offer adventure but also pace, excitement, relaxation and entertainment to passengers from across the world. Rodrigue and Notteboom (2013) noted that some cruise operators go very far in developing new entertainment concepts on board of their vessels, including golf simulators, surf pools, water parks, planetariums, on-deck movie screens, demonstration kitchens, ice-skating rinks, bungee trampolines, rock-climbing walls, etc. Onboard services account $20-30 \%$ of the total cruise line revenues so they make substantial efforts to capture additional revenue (Weaver, 2005b).

The purpose of this study is to reveal the Romanian passengers' perception about cruise destinations and their preferences when choosing a dream vacation like only a cruise ship can offer. It is well known that, the Romanian market faces difficulties in aligning with the world dynamics due to economic and geographical barriers. Although it has a generous seafront and the economic agents have reported high demand over the years, the cruise tourism is almost absent in the Black Sea. Fortunately, the positioning of this country in Europe makes embarkation from countries like Spain, Italy or Germany to be quite easy.

\section{Literature review}

A review of the literature regarding cruise industry reveals some empirical studies on tourism analyzing the motivations which encourage tourists to take a cruise vacation. According to these studies, the reasons to choose a cruise vary according to the passenger's cruise experience but not in relation to their cruise itinerary (Jones, 2011). 
Whyte (2018) states that destination image is an important factor when it comes to define how tourists perceive the cruise destination. Rodrigue and Noteboom (2013) note that the cruise industry sells the itinerary which is much more important than the destination itself. The local community experiences no significant net gain and the environment suffers a negative impact in some geographical areas (MacNeill, Wozniak, 2018).

The selection of ports of call and itineraries are carefully pondered to maximize the commercial potential and utilization of the ship assets. (Rodrigue, Notteboom, 2013). Sustainable tourism is based also on intercultural exchange between tourists and locals and it is very important that guests have the opportunity to see locals in their authentic environment. But mostly, passengers see themselves not as guests but mostly as customers (Polat, 2015).

MacNeill and Wozniak (2018) indeed highlight that economic multipliers are typically low with cruise tourism since passengers tend to eat, drink, sleep and spend their money on board with credit cards and most ships are registered in tax-haven ports. The researches about cruise passengers' satisfaction regarding the size of a cruise ship show that the vessel's real cost does not result in greater passenger satisfaction (CastilloManzano et al., 2018). The cruise industry in the Mediterranean has recorded considerable growth in the last decade and a significant number of ports have been included in cruise itineraries (Karlis, Polemis, 2018).

With the construction of all those larger ships with tremendous innovation in onboard features, a new hypothesis has surfaced in the literature to find out what is more important when deciding the primary destination of a cruise vacation: is it the itinerary with its port of calls or the ship itself (Jones, 2011).

Polat (2015) note that the infrastructure of many harbors is not ready to offer services to hundreds of passengers. At this point, financing of related investments is getting above the resources of these regions. Cruise ship companies started to invest more in infrastructure of such regions. In this case, the danger is represented by a strong dependency of locals on cruise companies and their economic and social influence. For the past few years, cruise companies began to invest increasingly in building up private clubs, hotels or private islands like the ones in Bahamas, Haiti or Honduras.

\section{Methodology}

Several international and local studies were used to better understand the demand in the cruise industry, both globally and especially on the Romanian market.

Reports presented by CLIA (2017) show that $33.7 \%$ of cruise ship capacity in lower berths belong to Caribbean area, with the largest ship deployment. The second largest cruise market is the Mediterranean with $18.7 \%$ of the cruise berth supply. The majority of the passengers taking a cruise in the Mediterranean and North Europe (83\%) are sourced from within Europe (CLIA Europe, 2016) which makes it an important and focused market on a global scale.

According to CLIA, in 2017, there were 26.75 million global cruise passengers sourced from North America (49\%), followed by Europe (26\%) and rest of the world accounted for the remaining $25 \%$. Rest of the World is illustrated by the fact that it accounts 
for about $82 \%$ of the world's population but only $25 \%$ of world cruisers (United Nations, 2018).

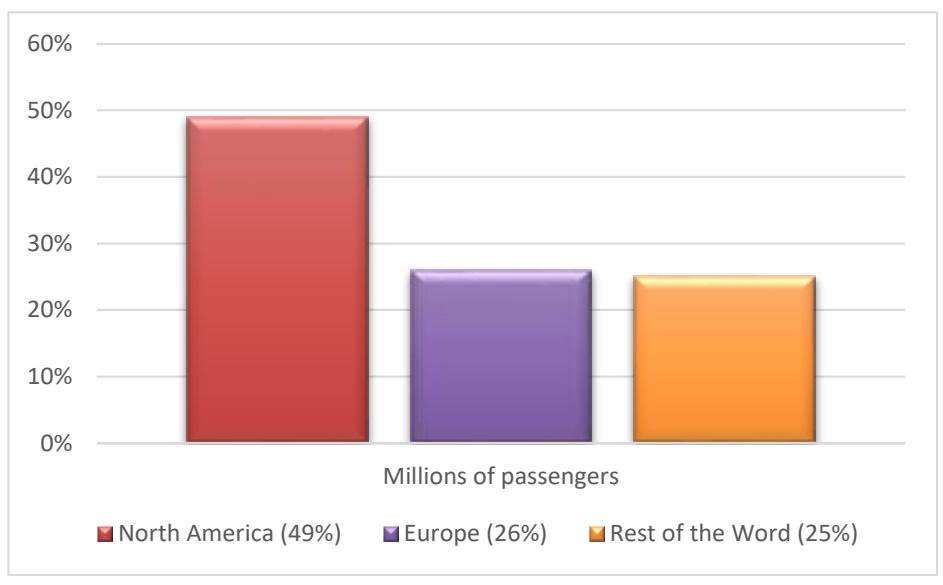

PICBE | 531

Figure 1. Global Distribution of Cruise Passengers by Source Market - 2017

Source: CLIA One reSource - The Global Economic Contribution of Cruise Tourism 2017

From the total global cruise passengers 13.12 million passengers were North Americans, 6.96 million tourists sourced from Europe and 6.67 million guests belong to countries like China, Brazil and Australia.

In Europe, 85\% of the 6.96 million passengers sourced from countries like Germany, United Kingdom, Italy, Spain and France. Germany and United Kingdom alone, accounted 4.1 million guests which represent 59\% from the total passengers among Europe. Countries as Austria, Netherlands, Norway and Switzerland contributed with $7.1 \%$ of European sourced passengers.

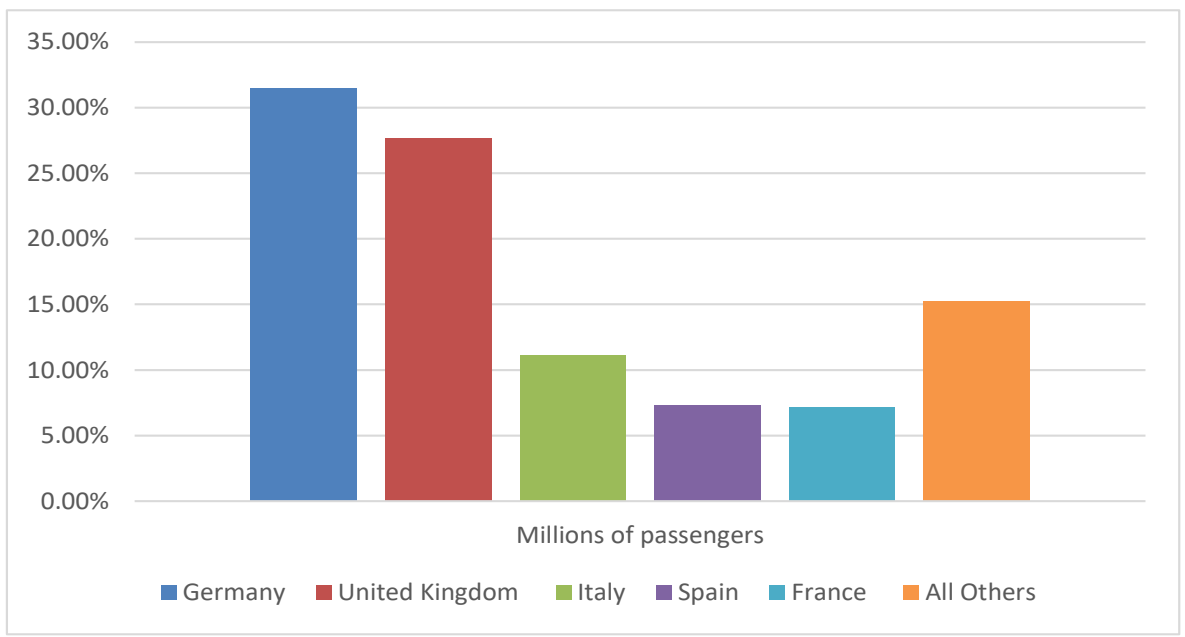

Figure 2. Distribution of Cruise Passengers Sourced from Europe - 2017

Source: CLIA One reSource - The Global Economic Contribution of Cruise Tourism 2017 
Romania is part of the rest of Europe, named in the table above "All others" that accounted 8.1\% from the total cruise passengers in 2017.

\section{Results and discussions}

Based on the recent evolution, in the next few years the European cruising industry is expected to flourish even more, due to the opening of new markets in Russian Federation and Central and Eastern Europe.

Among Europeans, the Mediterranean remains the most popular destination, with over 4.3 million visitors.

Table 1 - European Passengers - Top Key Destinations

\begin{tabular}{|l|l|l|l|}
\hline Key Destinations & $\mathbf{2 0 1 6}$ & $\mathbf{2 0 1 7}$ & $\mathbf{2 0 1 7}$ \\
\hline Western/Central Mediterranean & 2,264 & 2,241 & $-1 \%$ \\
\hline Northern Europe & 1,276 & 1,383 & $8 \%$ \\
\hline Caribbean/Bahamas/Bermuda & 855 & 933 & $9 \%$ \\
\hline Eastern Mediterranean & 774 & 687 & $-11 \%$ \\
\hline Canary Islands & 354 & 381 & $8 \%$ \\
\hline Baltics & 318 & 334 & $5 \%$ \\
\hline
\end{tabular}

Source: CLIA Europe - Europe Market Report 2017 Overview, March 2018

The ever-increasing demand of cruises is a result of cruise companies lowering the cruise fares as well as making major investments in larger ships. The increase in size means the creation of on board luxury facilities as well as other new attractions. Another trend of European cruise industry is extending the schedules of the ships from the East of the Mediterranean to the Black Sea with the inclusion of new docking ports as a result.

Although connected to the Mediterranean through the straits of Dardanelles and Bosphorus, the Black Sea is disadvantaged on the international cruise market due to a number of reasons. These reasons include a pronounced seasonality, a temperate climate much less pleasant that the Mediterranean climate, low tourism marketing within countries that have an opening to the Black sea and low interest from cruise companies regarding itineraries.

Table 2. Ports of Black Sea - Total Cruise Passenger Movements 2013-2017

\begin{tabular}{|l|l|l|l|l|l|l|l|}
\hline Port & $\mathbf{2 0 1 3}$ & $\mathbf{2 0 1 4}$ & $\mathbf{2 0 1 5}$ & $\mathbf{2 0 1 6}$ & $\mathbf{2 0 1 7}$ & $\mathbf{2 0 1 7} / \mathbf{2 0 1 6}$ & $\mathbf{2 0 1 7} / \mathbf{2 0 1 3}$ \\
\hline Constanta & 54614 & 69910 & 31856 & 6912 & 1891 & $-72,64 \%$ & $-96,54 \%$ \\
\hline Burgas & 5673 & 41763 & 7575 & 5833 & 1925 & $-67,00 \%$ & $-66,07 \%$ \\
\hline Varna & 2997 & 20939 & 3159 & 1109 & 791 & $-28,67 \%$ & $-21,37 \%$ \\
\hline Odessa & 91949 & 8506 & 6563 & 1242 & 1636 & 31,72 & $-98,22 \%$ \\
\hline Trabzon & 9032 & 17118 & 2280 & 452 & 206 & $-54,42 \%$ & $97,72 \%$ \\
\hline
\end{tabular}

Source: Cruise Activities in Med Cruise Ports - 2017 STATISTICS

When analysing the dynamics, the passenger numbers dropped by more than $90 \%$ in 3 out of 5 ports, while in Burgas the decrease was 65\%. This situation describes, without any doubt, a collapse of the cruise industry in the region, demonstrating its vulnerability to political and military tensions. 
Presently, the political situation in the Black Sea Basin is tense, due to the annexation of Crimeea by the Russian Federation in 2014 which has led to tourism being affected in the city of Odessa especially. Furthermore, the war in Syria generated a high number of migrant routes on the Black Sea and on top of this, the political situation in Turkey in 2016 was a devastating blow to the entire Black Sea tourism industry. This comes as a paradox due to the fact that the Black Sea itself is not a conflict area, but a very secure one known as incident free area, that benefits from military security and NATO protection on the coast of Romania and Bulgaria. All these factors led to the collapse of cruise tourism in the Black Sea.

Anyway, not having enough attractive ports to offer in this area, most of the major cruise lines have completely cancelled their itineraries in the Black Sea. Although a fairly recent appearance on the cruise destination map between $2013-2015$, the Black Sea is already facing an almost complete exclusion from the cruise industry's business landscape, due to the existing geo-political tensions.

Having this general view of the evolution in the cruise industry, the following study was conducted in Romania and aims to clarify the Romanian passenger's perception about cruise destinations and their preferences using a quantitative method, a survey sent to the most representative customers of this travel agency, that have shown interest to this kind of trip at least once. As a qualitative research method, a convenience sample of participants were recruited through the researcher's professional contacts in the cruise and travel industry. Interviews were conducted in Bucharest, Romania in 2018 and the participants were Romanian citizens ( 12 female and 8 male) who have cruised at least three times in the last three years. Previous cruise experience was an important fact as it allows respondents to provide significant amount of useful information and data for analyzing preferences when choosing a cruise destination.

The questionnaire contains a total of 20 questions about personal experiences, preferences, expectations and tourists' intentions about future cruise holidays. After two weeks, the author received 60 complete questionnaires. The total number of cruises among the participants was 374, with an average of 6.6 cruises per person. A key question in the survey was the one through which the author wanted to find out the main factors that might influence the passenger's choice when they book their experience.

Table 3. The evolution of the number of passengers that bought a cruise from Croaziere.net Travel Agency

\begin{tabular}{|l|l|l|l|l|l|}
\hline Year & 2014 & 2015 & 2016 & 2017 & 2018 \\
\hline Passenger no. & 3600 & 4500 & 5500 & 8000 & 1.100 \\
\hline Percentage growth & $10 \%$ & $20 \%$ & $20 \%$ & $45 \%$ & $37.5 \%$ \\
\hline
\end{tabular}

Source: Croaziere.net Travel Agency - Internal Data

A number of 25 survey respondents had already embarked from Constanta port during 2013 and 2015 when different ships belonging to MSC Cruises and Costa Cruises used it as a homeport.

The author has been working for the past five years for a renowned travel agency in Romania engaged in the sale of cruises since 2005, has sailed on board seven different 
cruise ships in Europe and Caribbean as a tour leader for Romanian groups and is using this experience with cruise passengers, in this article.

\section{Conclusion}

The Western Mediterranean side is dependent of cruise ports in Italy and Spain. The leader is found to be the port of Barcelona, with the highest traffic, being an accessible port for passenger's embarkation from all over the world and an attracting beautiful city, well worth visiting.

Following, the port of Civitavecchia (near Rome, Italy) is the second largest homeport of the Western Mediterranean and the most accessible port for Romanian passengers.

Most of them would choose a non-expensive flight to the city of Rome and book one or two accommodation nights in order to visit the city and the Vatican. It is very easy after this to arrive in Civitavecchia by train and to embark in less than two hours on their cruise ship.

Being easily accessible by car, the ports of Genoa and Savona are another popular option for Romanians who choose this means of transportation. Last year, these ports, along with the port of Marseille, have seen a growth in development, under the influence of cruise lines like MSC Cruises and Costa Cruises, who chose them as a cruise hub in order to avoid queues during embarkation process in other crowded port terminals, to be accessible for any nationality passengers and to better serve all markets.

For the Eastern Mediterranean, the port of Venice is the undisputed leader, servicing more than half of the homeport market and further investments in expansion and port facilities are announced. Moreover, port cities like Trieste, Bari and Athens are also accessible for the Romanian passengers who already visited Venice and would choose to visit Greek Islands together with Croatia and Montenegro.

The most important aspect for a Romanian guest is the itinerary of the cruise ship, followed by the price and the embarkation port. Furthermore, the number of sea days, the service quality onboard and the cruise ship company is also relevant when choosing a cruise vacation. The respondents were asked to choose their dream cruise destination and the Caribbean Islands was the first one in their preferences, the second one was Asia and the third one Norwegian Fjords with Scandinavia. Moreover, for the question regarding European destinations preferred, cruise itineraries which include the Mediterranean Sea and the Greek Islands are on the bottom three places, whilst destinations from Northern Europe like Norwegian Fjords occupy the first three places. However, based on the company's sales for the past year, it seems that the Mediterranean remains one of the favorite destinations, overall. Furthermore, $90 \%$ of the respondents will cruise again in less than one year and half of them had already booked a new itinerary for the next 6 months.

The geographical positioning of Romania in Europe makes embarkation from countries like Spain, Italy, Greece, Sweden or Germany quite comfortable since the airlines offer very convenient direct flights to different cruise hubs like Rome for Civitavecchia, Barcelona, Venice, Athens, Hamburg, Stockholm.

Even though their favorite cruise lines seem to be MSC Cruises, Pullmantur, Costa Cruises and Celestyal Cruises because of non-expensive cruise rates, most Romanian cruise passengers are also able to differentiate between Mass Market cruise companies, and Premium or Luxury lines, which have better reviews. The main reasons for choosing a 
Premium cruise line would be a better crew - passenger ratio and more space per passenger, as it is a significant aspect when talking about customer experience on board. Regardless their nationality, passengers value more the highly rated vessels which belong to cruise lines with a greater number of years of experience in the cruise market.

According to their responses, Romanian passengers choose surely to seek the services of a travel agency when booking a cruise vacation and the average spending for a trip is $1000 €$ per person for a seven nights cruise. For the Romanian market and the Eastern European area in general, the most accessible ports for starting a cruise are Civitavecchia - the closest port to Rome - and Barcelona - the main cruise hub in Europe.

The Romanian cruise market is still developing and for the moment it is considered an emerging market for the cruise lines all over the world. The cruise industry started increasing year to year globally and the Romanian market was not an exception. As a result, if in the first few years there were only a few tens of cabins sold, eventually this number turned into hundreds. At the moment, from Romania, around 8000 passengers travel on board cruise ships round the world, with a few thousand cabins sold annually (and growing).

\section{References}

Business Research \& Economic Advisors (2014). The contribution of the North American cruise industry to the US economy in 2013. Retrieved from http://www.cruising.org/docs/default-source/research/us-economic-impact-study2013.pdf?Sfvrsn=2.

Castillo-Manzano, J.I., Castro-Nuno, M., Lopez-Valpuesta, L. (2018). When Las Vegas takes to the sea: new trends in cruising. Tourism Economy, 24, 135-140.

Castillo-Manzano, J.I., Castro-Nuno, M., Lopez-Valpuesta, L. (2018). What does cruise passengers' satisfaction depend on? Does size really matter? International Journal of Hospitality Management, 75, 116-118.

CLIA. (2017). 2016 state of the industry [online] Available at: https://www.cruising. org/about-the-industry/research/2016-state-of-the-industry [Accessed 5 May 2018].

CLIA Europe. (2016). Contribution of cruise tourism to the economies of Europe 2015. Available at: https://www.cliaeurope.eu/images/downloads/reports/ Contribution_Cruise_Tourism_to_Economies_of_Europe_2015.pdf. Accessed 22.04.2018.

Cruise Market Watch (2018). The Cruise Industry's destination for market share, size and marketing trends. Retrieved from: (https://cruisemarketwatch.com) Accessed on 18.11.2018.

Dowling, R. (2006). Cruise ship tourism (1 ${ }^{\text {st }}$ ed, pp. 95-104). Wallingford.

Garin, K. A. (2005). Devils on the deep blue sea: The dreams, schemes, and showdowns that built America's cruise-ship empires. New York: Plume.

Jones R. V. (2011). Motivations to cruise: An itinerary and cruise experience study. Journal of Hospitality and Tourism Management, 18, 30-40.

Karlis, T. \& Polemis, D. (2018). Cruise homeport competition in the Mediterranean. Tourism Management, 68, 168-176.

MacNeill, T. \& Wozniak, D. (2018). The economic, social, and environmental impacts of 
cruise tourism. Tourism Management, 66, 387-404.

Mancini, M. (2011), The CLIA Guide to the Cruise Industry, Delmar, Cengage Learning.

Polat, N. (2015). Technical Innovations in Cruise Tourism and Results of Sustainability. Procedia - Social and Behavioral Sciences, 195, 438-445.

Rodrigue, J. \& Notteboom, T. (2013). The geography of cruises: Itineraries, not destinations. Applied Geography, 38.31-42.

United Nations, (2018) Available at http://data.un.org/. Accessed on 18.11.2018.

Weaver, A. (2005b). Spaces of containment and revenue capture: 'super-sized' cruise ships as mobile tourism enclaves. Tourism Geographies, 7(2), 165-184.

Whyte, L. J. (2018). Eliciting cruise destination attributes using repertory grid analysis. Journal of Destination Marketing \& Management, 10, 172-180. 